\title{
Next to Nothing: The Impact of the Norwegian Introduction Programme on Female Immigrants' Labour Market Inclusion
}

\author{
ELISABETH UGRENINOV* (iD) AND LENA MAGNUSSON TURNER** \\ *Norwegian Social Research, Oslo Metropolitan University, Stensberggata 26, 0130 \\ OSLO, Norway \\ email: elisabeth.ugreninov@oslomet.no \\ **Norwegian Social Research, Oslo Metropolitan University, Stensberggata 26, 0130 \\ OSLO, Norway \\ email:Imtu@oslomet.no
}

\begin{abstract}
In 2003, Norway implemented an 'Introduction Programme' that aimed to increase labour market inclusion among newly arrived immigrants. Its main objectives were to facilitate free courses in Norwegian language training and social studies, and education or on-the-job training. The participants were given an allowance to attend the programme. This paper uses administrative register data to evaluate the effect of the Norwegian introduction programme on female immigrants' employment and earnings prospects. The sample consists of female immigrants from Asia or Africa who immigrated to Norway 18 months before or after the implementation of the introduction programme. The study measures their probability of being employed and their mean earnings 4-6 and 7-9 years after immigration. The results show that the Norwegian introduction programme had a small but significant effect on women's employment, but not on their earnings. This article suggests that the small effect of the programme on employment and non-effect on earnings may imply a displacement effect rather than an improvement in language skills and labour market skills.
\end{abstract}

Keywords: Immigration; integration policy; labour market integration

\section{Introduction}

Immigrants' substantial disadvantages in the labour market are a major barrier to achieving the United Nations Sustainable Development Goal 8, which promotes inclusive and sustainable economic growth, full and productive employment and decent work for all. As documented in previous research, there are large employment gaps between native-born and immigrant residents, particularly among women, in all Western European countries (Bratsberg et al., 2017; Heinesen et al., 2013; Pyrhönen et al., 2017; Schultz-Nielsen, 2017). Poor hostcountry human capital among immigrants, such as language, formal skills and work-relevant experience, have been put forward as possible explanations for poor labour market inclusion (Shields and Price, 2002; Chiswick and Miller, 
2007; Chiswick and Miller, 2010; Bloch, 2007). To address such challenges and to improve immigrants' employment opportunities, Norway implemented an 'Introduction Programme' on 1 September 2003, facilitating free courses in Norwegian language training and social studies, and education or on-the-job training. Refugees were obliged to participate, while it was voluntary for family members reunited with refugees (family-reunited immigrants): however, incentives for participation were provided through allowances.

Recent research focusing on the Norwegian introduction programme (NIP) indicates an insignificant or weak effect on employment or earnings. However, most of the Norwegian studies suffer from selection bias, as they explicitly study immigrants participating in the NIP or cohorts that immigrated several years after its introduction (Djuve et al., 2017; Hernes et al., 2019; Røed et al., 2019). A prerequisite for evaluating labour market programmes is the possibility to compare employment or earnings between groups that are as equal as possible, except for policy treatment (Angrist and Pischke, 2009), which is not possible when using cohorts that have immigrated several years after the implementation of the NIP. One Norwegian study focuses on the introduction of the NIP and addresses how education and year of residence affect different integration paths, such as dependency on social security benefits and earnings (Røed et al., 2019). Although existing research has contributed useful knowledge, more research on the effectiveness of integration programmes targeting immigrants is needed.

To extend current knowledge, we explore how the NIP affects refugees' and family-reunited immigrants' prospects of employment and earnings compared to refugees and family-reunited immigrants not covered by the reform. We restrict our sample to the largest immigration groups eligible for the NIP, which are immigrants from Asian or African countries (AAC). We employ administrative register data and examine the exogenous change in facilitating the achievement of host-country human capital (introduction of the NIP), determined by the date of immigration. Refugees and family-reunited immigrants, who immigrated to Norway 18 months before the reform date are defined as non-treated, while those who immigrated 18 months after this date are defined as treated. Non-treated and treated immigrants arrived in different time periods: thus, a simple comparison between these two groups is not sufficient to measure the effect of the NIP on labour market inclusion. To address this problem, we compare refugees and family-reunited immigrants' outcomes with a control group that immigrated in the same time period but were not eligible for the NIP; consisting of women from AAC who immigrated to marry ethnic Norwegian men, Norwegian-partner immigrants. The effect of the NIP is thus identified by comparing the employment and earning gaps between the respective immigration groups and the control group before and after the introduction of the NIP. We further include a fourth group of women from AAC who 
immigrated to marry Norwegian men with a background (often via their parents) from the same country of origin, immigrant-partner immigrants, and employ an analogue comparison to Norwegian-partner immigrants. As both groups are not covered by the NIP, analogue analyses will capture time-varying conditions in the labour market that may affect employment and earnings prospect.

The Norwegian labour market represents an interesting case - the generous welfare state relies on a dual-earner model focusing on gender equality to facilitate work and family life with the extended use of active labour market measures. At the outset, female immigrants are less employable due to their lack of formal skills and language comprehension. By examining an explicit policy change, this study will be relevant for other countries' development of policies aimed at facilitating the inclusion of groups that face barriers to employment. Theoretically, evaluation of the NIP widens our understanding of increased host-country human capital on female immigrants' employment prospects. We believe that we have designed an advanced solution to expand knowledge on the effectiveness of introduction programmes, which is important in order to develop policy measures that facilitate labour market inclusion of disadvantaged groups.

This paper is divided into four sections. The first section provides a brief overview of previous research, our theoretical framework and the institutional context. The second section describes the methodological design and descriptive analyses of the outcomes. In the third section, we analyse and evaluate the effect of the NIP on female immigrants' employment and earnings. We present our discussion and conclusions in the final section.

\section{The Norwegian immigration and labour market inclusion policy}

In the early 1970s, immigration to Norway consisted of male labour immigrants from Pakistan and Turkey. The authorities made little effort to integrate them until they went from being temporary workers to settling in Norway with their families. In 1975, Norway froze labour immigration from less developed countries, except in the case of family reunification. The lack of policy measures for integration combined with a non-existent settlement policy may have contributed to the segregation of these populations in central areas, resulting in poor progress in their Norwegian culture and language skills. Later, immigration to Norway was dominated by humanitarian motives followed by family reunification. The influx of refugees following the war in Bosnia-Herzegovina increased the need for a settlement policy. In response, the system for settling refugees was altered in 2001 (White Paper No. 23: 2003-2004), refocusing it to settle refugees all over Norway - in other words, refugees were not encouraged to find housing by themselves.

A further strategy to improve integration, especially in the labour market, was the introduction of the NIP. This study focuses on the introduction of the 
NIP: thus, a complete description of the changes that have been made is not relevant here (e.g. Hernes et al, 2019 or Djuve and Kavli, 2019). The NIP's main objectives were to give participants basic skills in Norwegian, provide basic insights into Norwegian society (courses lasting up to 600 hours) and prepare them for participation in professional life. The municipalities were responsible for organising these programmes and were obliged to offer the NIP free of charge within three months after immigration. Participation in the programme was voluntary for family-reunited immigrants and compulsory for all refugees, with few exceptions such as adequate skills in the Norwegian language. However, there were strong economic incentives for participation. Immigrants participating in the NIP were entitled to financial support paid as a taxable salary. The annual benefit was twice the National Insurance basic amount (the annual BA in 2003 was EUR 6,333). Participants under 25 years of age received $2 / 3$ of the benefit. The right to financial support only applied in the first municipality where the immigrant settled. The programme could last for up to two years, while approved leaves of absence, for e.g. poor health or parental leave, could prolong the programme for a total of up to three years. The NIP was, and is still, often highlighted as an example of a well-developed qualification measure for newly arrived immigrants.

\section{Why should we expect the NIP to affect labour market inclusion?}

Human capital theory provides a useful explanation for the core intention of the NIP, explicitly, to improve newly arrived immigrants' skills in the Norwegian language and social studies, in addition to providing necessary education and on-the-job training to enhance their labour market inclusion. Human capital theory has been widely used to explain labour market participation and how talent, skills and capability are decisive for better job opportunities (e.g. Becker, 1985). However, there is an important distinction within this, i.e. whether the human capital is acquired in the host country or in the country of origin. Some researchers argue that the latter is less valued by employers in host nations (Friedberg, 2000; Bratsberg and Ragan, 2002; Bloch, 2007; Arendt et al., 2016). Human capital theory emphasises explanations focusing on employers' uncertainty with respect to origin-country human capital and skill transferability.

Host-country language efficiency is one of the key determinants of hostcountry human capital related to successful integration into society and labour market participation. Host-country language training is correspondingly a key component for almost every country that facilitates introduction programmes for immigrants, although the organisation of such language training varies considerably (Djuve and Kavli, 2019). In general, learning a new language is often a difficult and time-consuming process, which may involve high economic costs - 
such as tuition fees and course materials - as well as opportunity costs - such as forgone earnings from employment. The implementation of the NIP was based on such arguments, and the assumption that free language courses and financial support paid as a taxable salary would equalise differences that might arise because of geographical place of residence, gender and financial resources. Female immigrants might experience additional barriers when attending language courses, such as poor childcare facilities, language classes within school hours and absence of single sex classes (Dumper, 2002). Facilitating language courses for female immigrants is probably especially important; findings suggest a correlation between female refugees' language proficiency, their health, and the extent of their formal and personal networks, which in turn enhance access to education and employment (Cheung and Phillimore, 2017). Studies from the Nordic countries strengthen this assumption where findings indicate a positive correlation between language training and employment (Clausen et al., 2009; Delander et al., 2005; Djuve et al., 2017; Sarvimäki and Hämäläinen, 2016).

An important aspect of the NIP is on-the-job training, with similarities to active labour market programmes (ALMP), but with less focus on job-seeking courses and higher ambitions of on-the-job training tailored to individual needs. A meta-analysis study by Butschek and Walter (2014) indicates that immigrants' probability of employment increases if ALMP measures are closely related to the labour market. In a Danish context, Clausen et al. (2009) found a positive employment effect among newly arrived refugees and family-reunited immigrants solely in private-sector subsidised employment, while Heinesen et al. (2013) found positive effects of education, training and direct employment programmes on employment among non-Western immigrants with long residence time. Studies from Norway indicate no employment effect of on-the-job training among immigrants in general (Hardoy and Zhang, 2010), or among participants in the NIP (Djuve et al., 2017). A Finnish study found a positive earning effect of a reform that restructured ALMP for unemployed immigrants. The reform did not affect the total number of days of training but adapted the training more to the immigrants' needs, such as language courses, training in civic and working life skills and vocational training (Sarvimäki and Hämäläinen, 2016). In 2003, Sweden introduced a six-month introductory programme aimed at immigrants with a background outside the Nordic region, who were considered able to take a job immediately, but were at risk of becoming long-term unemployed. Participants judged suitable for the programme were offered free courses in basic reading and writing training and assigned a caseworker focusing on supported employment and careful matching between participants and employers. Studies evaluating this reform found a significant treatment effect on employment probabilities among participants (Åslund and Johansson, 2011; Joona and Nekby, 2012). However, although municipalities were randomly assigned, participants were positively selected to participate in the programme which might have affected the results. 
Studies examining the employment effect of ALMP in general or targeting immigrants may not be transferable to studies on integration programmes. The main difference is that immigrants covered by integration programmes are not selected due to periods of unemployment history, skills or motivation, which are often criteria for participation in ALMP or similar programmes. In our example, immigrating to Norway after a specific given date was pivotal for participation in the NIP. Based on these arguments, the facilitation of free courses in Norwegian language and social studies, and the focus on on-the-job training, this study expects the NIP to have a positive effect on treated immigrants' acquisition of host-country human capital, and hence enhance their employment prospects compared to nontreated immigrants. We further assume that the NIP will not affect immigrants who are ineligible for the NIP, such as Norwegian-partner immigrants and immigrantpartner immigrants, in terms of their labour market inclusion.

Thus, the study hypothesises that the employment gap between non-treated immigrants (refugees and family-reunited immigrants), and Norwegian-partner immigrants, is greater than the employment gap between treated immigrants (refugees and family-reunited immigrants), and Norwegian-partner immigrants 4-6 years after immigration ( $\left.\mathrm{H}_{1}\right)$.

Another concept behind the NIP was that increased host-country human capital would create better jobs and hence long-lasting positive effects on employment and earnings. Thus, the study hypothesises that the employment gap between non-treated immigrants (refugees and family-reunited immigrants), and Norwegian-partner immigrants, is greater than the employment gap between treated immigrants (refugees and family-reunited immigrants), and Norwegianpartner immigrants 7-9 years after immigration $\left(\mathrm{H}_{2}\right)$.

The above hypotheses assume that the NIP will increase the general level of host-country human capital through improved language skills, knowledge of civics and on-the-job training, and thus increase the employability of treated refugees and family-reunited immigrants.

\section{Data and empirical framework}

This study draws on comprehensive longitudinal administrative datasets in the period from 2000 to 2013 collected from several national registers under the control of Statistics Norway. The sample was restricted to immigrants from AAC who immigrated to Norway 18 months before or 18 months after the reform date, 1 September 2003. Focusing on continents instead of countries, where we further organised AAC immigrants into the World Bank's official classification (WBCc) of the world's economies, provides us with a larger empirical basis for our analysis and thus more robust results, although at the cost of hidden internal variation. Furthermore, the study only includes individuals with officially registered information on maternal birth country and immigration status. Individuals who died or moved away from Norway during the measurement 


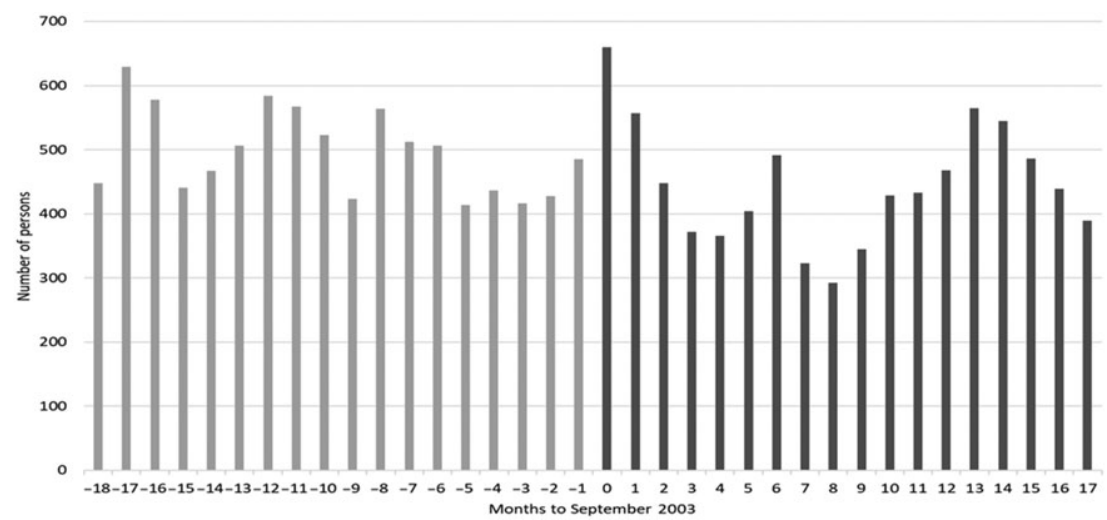

FIGURE 1. Histogram of immigration among female immigrants from AAC. Note: Zero at the $\mathrm{x}$-axis corresponds to the reform date, -18 to -1 corresponds to the months before the reform date, $0-17$ corresponds to the months after the reform date.

period were excluded. Due to age limitations relating to participation in the NIP and expected occupational participation in the analysis period, the sample is based on individuals aged $18-55$ at the time of settlement. These restrictions leave a total sample size of 9,780 individuals, comprising refugees $(2,544)$, family-reunited immigrants $(2,021)$, immigrant-partner immigrants $(2,361)$ and Norwegian-partner immigrants $(2,854)$.

A crucial assumption to identify the effect of the NIP on labour market inclusion is that the implementation of the NIP was exogenous. If the immigrants included in the sample could manipulate their time of immigration, the continuity assumption underlying the identification may be violated. Although the reform was implemented on 1 September 2003, the municipalities were responsible for its implementation and this was in some municipalities finalised in 2004. Differences in the time of implementation affect the start-up date among immigrants covered by the NIP, but do not affect their right to participate in the programme.

To test whether the implementation of the NIP was exogenous, Figure 1 contains a histogram of the sample's immigration date. As the figure indicates, it is unlikely that the timing of the introduction of the NIP was decisive for general immigration to Norway.

Various measures of labour market inclusion exist, such as earning, number of working hours or performed work for pay or profit for at least one hour in the reference week; thus, a precise definition is difficult to formulate. We use four outcomes of labour market inclusion derived from individual annual earnings, which includes wages and salaries from paid employment as well as net entrepreneurial income and gross taxes measured at the end of the year. The four outcomes are: 1) employed 4-6 years after immigration, defined as having mean earnings above one BA for each respective year $\left.{ }^{1}, 2\right)$ employed 7-9 years 
after immigration, defined as having mean earnings above one BA for each respective year ${ }^{2}$, 3) mean earnings 4-6 years after immigration among those defined as being employed in the same period, 4) mean earnings 7-9 years after immigration among those defined as being employed in the same period.

All refugees and family-reunited immigrants who immigrated to Norway on 1 September 2003 and over the following 18 months were covered by the NIP (treated), and those who immigrated 18 months before were not (nontreated): thus, it is possible to compare the outcomes between these two groups in order to identify the effect of the NIP on labour market inclusion. However, a simple comparison between treated and non-treated groups may capture differences in timing of immigration and macro-economic conditions that affect the labour market differently and not the intended effect of the NIP on employment and earnings. To address this problem, we included Norwegian-partner immigrants as a control group, since they were not eligible for the NIP in the analysis period of interest but immigrated in the same time period.

By including a control group that is not covered by the reform, the logic behind a difference-in-differences approach can be used (e.g. Angrist and Pischke, 2009). We thereby observed the differences in the employment and earning gaps between pairs of immigration groups - NIP-eligible divided into nontreated and treated, and control groups. Accordingly, all analyses were performed for each pair, with Norwegian-partner immigrants as a control group (A: refugees/ Norwegian-partner immigrants, B: family-reunited immigrants/Norwegianpartner immigrants, C: immigrant-partner immigrants/Norwegian-partner immigrants). This design is based on the assumption that the employment and earning gaps between refugees and family-reunited, and Norwegian-partner immigrants, before the introduction of the NIP, would capture the counterfactual gaps if the NIP had not been implemented (Angrist and Pischke, 2009). The last pair of immigrants, C, was included as a robustness check; here, the introduction of the NIP can be considered as a placebo-NIP because neither group was covered by the reform. This comparison clarifies whether any difference between the other pairs was driven by calendar effects or by a strategic immigration pattern (e.g. those who immigrated after the introduction of the NIP were more employable than those who immigrated before the introduction).

Two different analyses were used for the two measurement periods of 4-6 years and 7-9 years after immigration: 1) a linear probability model to estimate employment, and 2) an ordinary least squares (OLS) to estimate mean earnings. All the analyses were run separately for the paired groups:

$$
\begin{aligned}
& \text { Empl }_{i}=\alpha_{i}+\beta \mathbf{X}_{i}+\chi \text { Treatment }_{i}+\gamma \text { Treatment }_{i}^{*} \mathbf{X}_{i}+\sigma \mathbf{Z}+\epsilon_{i} \\
& \text { Earning }_{i}=\alpha_{i}+\beta \mathbf{X}_{i}+\chi \text { Treatment }_{i}+\gamma \text { Treatment }_{i}{ }^{*} \mathbf{X}_{i}+\sigma \mathbf{Z}+\epsilon_{i}, \\
& \text { if Empl }>\mathrm{BA}_{t_{1}=4,5,6} \& \mathrm{t}_{2}=7,8,9
\end{aligned}
$$


As an indicator variable, Treatment is equal to one for those who immigrated after the introduction of the NIP, and zero among those who immigrated before the reform date. $\mathbf{X}$ is a vector of predetermined variables (type of immigration group). The interaction variable, $\gamma$ Treatment $_{i}{ }^{*} \mathbf{X}_{\mathrm{i}}$, is the coefficient of interests and can be understood as a measure of how the NIP affected employment and earnings among immigrants in the treatment group. $\mathbf{Z}$ is included as a vector of predetermined variables. Age is measured at the time of immigration, and is a continuous variable ranging from 18 to 55 . Economic region is a set of 54 dummy variables based on municipalities and their commuting area. Individuals' affiliation to economic region is based on their first settlement municipality and will capture regional variation in the organisation and timing of the implementation of the NIP and regional differences in labour market opportunities. WBcc is organised into four income groups: low, lower-middle, upper-middle and high-income countries. Countries are classified each year on 1 July, based on the estimate of their GINI per capita for the previous calendar year. The classification for 2003 is used in this study. Affiliation to WBcc is based on the individuals' officially registered information on maternal birth country. Including $\mathrm{WBcc}$ in the analyses will capture structural conditions in the country of origin that may affect future life chances in the destination country. Including $t_{1}$ and $t_{2}$ symbolises years after immigration, which is the measurement period. Finally, $\epsilon_{i}$ is an error term. The study accessed several registers to retrieve other background information upon arrival for all individuals, which are mainly used to define the sample, selection into subgroups and for descriptive purposes.

Based on the empirical strategy described, we believe that any change in employment and earnings gaps between refugees and family-reunited immigrants, and Norwegian-partner immigrants after the introduction of the NIP can be understood as an impact of the NIP on labour market inclusion. If this argument holds, there should be a significant reduction in the employment and earnings gap between Norwegian-partner immigrants and treated immigrants (refugees and family-reunited); moreover, NIP should not have an impact on immigrant-partner immigrants. However, all NIP-eligible immigrants did not participate: thus, this study will capture an intention to treat effect of the specific policy change among refugees and family-reunited immigrants from AAC.

All analyses of the four outcome measures follow the same model specification. The first model, for transparency, only included dummies for treatment and migrant group, and the interaction term between the two dummies. In model 2, we further included fixed effects for economic region for completeness to show sensitivity with respect to regional variation in labour market opportunities and the organisation and timing of the implementation of the NIP. Age on arrival and WBcc were further included in Model 3. In all three models, the constant refers to Norwegian-partner immigrants who immigrated to Norway 18 months before the introduction of the NIP. Treatment refers to 
Norwegian-partner immigrants who immigrated to Norway 18 months after the introduction of the NIP. Migrant group refers to those who immigrated to Norway 18 months before the introduction of the NIP (refugees in analysis A, family-reunited immigrants in analysis B, immigrant-partner immigrants in analysis C). Treated $x$ migrant group refers to immigrants (e.g. refugees in analysis A, and so forth) who immigrated to Norway 18 months after the introduction of the NIP.

\section{Results \\ Descriptive analyses}

Table 1 reports summary statistics on predetermined variables by immigration group. The summary statistics indicate a significant difference in the number of family-reunited immigrants who immigrated before or after the reform date, whereas there is no such difference among the other immigration groups. There is a higher proportion of immigrants from low-income and lower-middle income countries after the NIP. These differences may underestimate the effect of the NIP on labour market inclusion: however, Model 3 controls for such differences. Age and number of children at arrival are balanced between those who immigrated before and after the introduction date in all the immigration groups.

Figure 2 shows that the probability of employment is relatively stable between the first and second measurement period within each immigration group, and highest among Norwegian-partner immigrants ( $76 \%-78 \%)$ followed by immigrant-partner immigrants (50\%-53\%), refugees (46\%-50\%), and familyreunited immigrants $(38 \%-41 \%)$.

The graphical presentation of the short-term and long-term mean earnings gives a slightly different picture. It is worth noting that earnings are conditional on employment in the measurement period. The mean earnings among Norwegian-partner immigrants is just above 2.5 BA 4-6 years after immigration, whereas it is about one BA less in the same period among immigrantpartner immigrants, equivalent to EUR 6,998 per year. The estimates of mean earnings are slightly lower among refugees and family-reunited immigrants compared to immigrant-partner immigrants. All immigration groups, except family-reunited immigrants, experienced an increase in earnings from the first to the second measurement period.

\section{The short-term effect of the NIP}

This study hypothesised that the implementation of the NIP facilitated an increase in treated immigrants' host-country human capital, which could improve their employment and earnings prospects compared to non-treated immigrants $\left(\mathrm{H}_{1}\right)$. To test this hypothesis, we employ two separate analyses where employment is the dependent variable in the first, and earnings in the 
TABLE 1. Summary statistics of females from AAC before and after the introduction of the NIP

\begin{tabular}{|c|c|c|c|c|c|c|c|c|}
\hline \multirow[b]{2}{*}{ Before the NIP } & \multicolumn{2}{|c|}{ Refugees } & \multicolumn{2}{|c|}{$\begin{array}{l}\text { Family-reunited immi- } \\
\text { grants }\end{array}$} & \multicolumn{2}{|c|}{$\begin{array}{l}\text { Immigrant-partner } \\
\text { immigrants }\end{array}$} & \multicolumn{2}{|c|}{$\begin{array}{l}\text { Norwegian-partner } \\
\text { immigrants }\end{array}$} \\
\hline & Mean & Std. Dev. & Mean & Std. Dev. & Mean & Std. Dev. & Mean & Std. Dev. \\
\hline Age on arrival & 29.67 & 8.40 & 30.20 & 8.13 & 26.73 & 6.67 & 30.59 & 7.09 \\
\hline $\begin{array}{l}\text { Number of children on arrival } \\
\text { Country background }\end{array}$ & 0.68 & 0.89 & 0.88 & 0.93 & 0.58 & 0.64 & 0.40 & 0.57 \\
\hline Low-income & 54.26 & & 29.56 & & 12,10 & & 1.44 & \\
\hline Lower-middle & 15.74 & & 11.96 & & 55.29 & & 9.31 & \\
\hline Upper-middle & 29.18 & & 54.82 & & 28.40 & & 62.41 & \\
\hline High-income & 0.82 & & 3.66 & & 4.20 & & 26.84 & \\
\hline $\begin{array}{l}\mathrm{N} \\
\text { After the NIP }\end{array}$ & 1,220 & & 1,421 & & 1,190 & & 1,386 & \\
\hline Age on arrival & 30.0 & 8.19 & 29.3 & 7.65 & 26.72 & 6.35 & 90.98 & 7.17 \\
\hline $\begin{array}{l}\text { Number of children on arrival } \\
\text { Country background }\end{array}$ & 0.74 & 0.90 & 0.81 & 0.90 & 0.55 & 0.4 & 0.39 & 0.58 \\
\hline Low-income & 50.98 & & 30.17 & & 9.82 & & 1.36 & \\
\hline Lower-middle & 25.53 & & 18.00 & & $54 \cdot 31$ & & 11.92 & \\
\hline Upper-middle & 23.04 & & 44.50 & & 32.02 & & 64.65 & \\
\hline High-income & 0.45 & & $7 \cdot 33$ & & 3.84 & & 22.07 & \\
\hline $\mathrm{N}$ & 1,324 & & 600 & & 1,171 & & 1,468 & \\
\hline
\end{tabular}



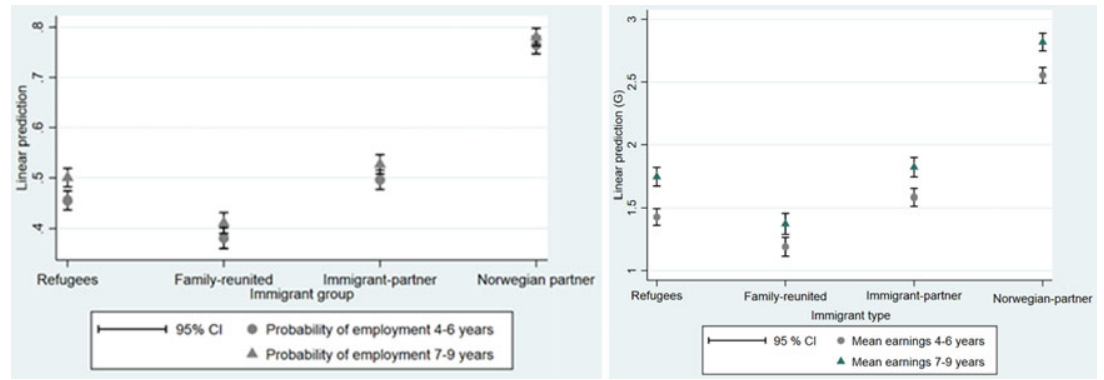

FIGURE 2. Graphical presentation of estimates of the probability of employment and earnings among the respective immigration groups 4-6 and 7-9 years after immigration.

second. For both dependent variables, separate analyses were performed within each pair where Norwegian-partner immigrants are set as a control group. We further implemented three models: however, comments in the text refer to estimates in Model 1.

Table 2 presents the results from the first set of analyses which investigate the short-term employment effect of the NIP. The main findings, in column A, show that $76 \%$ of Norwegian-partner immigrants (constant) are employed 4-6 years after immigration. As expected, there are no significant differences between Norwegian-partner immigrants who immigrated before versus after the introduction of the NIP (treatment). Refugees who immigrated before the reform date (non-treated) have a 35-percentage point lower probability of employment compared to Norwegian-partner immigrants. The interesting aspect of this analysis is the interaction term (treatment $x$ migrant group), which is significant and positive (0.08). This finding confirms that the NIP reduced the employment gap between Norwegian-partner immigrants and refugees by eight percentage points, which means that treated refugees have a higher probability of employment compared to non-treated refugees 4-6 years after immigration.

The same pattern is found among family-reunited immigrants (column B). In general, family-reunited immigrants have a 41-percentage point lower probability of employment 4-6 years after immigration compared to Norwegianpartner immigrants (0.76), which indicates that family-reunited immigrants are also less employed than refugees. On the other hand, the employment effect of the NIP among family-reunited immigrants is significant and positive at 9-percentage points, and thus on a par with treated refugees.

The municipal differences in the implementation and organisation of the NIP and regional differences in the labour market raised concerns about biases that may have affected employment and earnings. There were differences in age between the immigration groups: however, as there were no significant differences in age within each immigration group, including age in the analyses would not affect the interaction terms but rather sharpen the estimates. Including fixed 
TABLE 2. Linear probability model of immigrants' employment 4-6 years after immigration to Norway

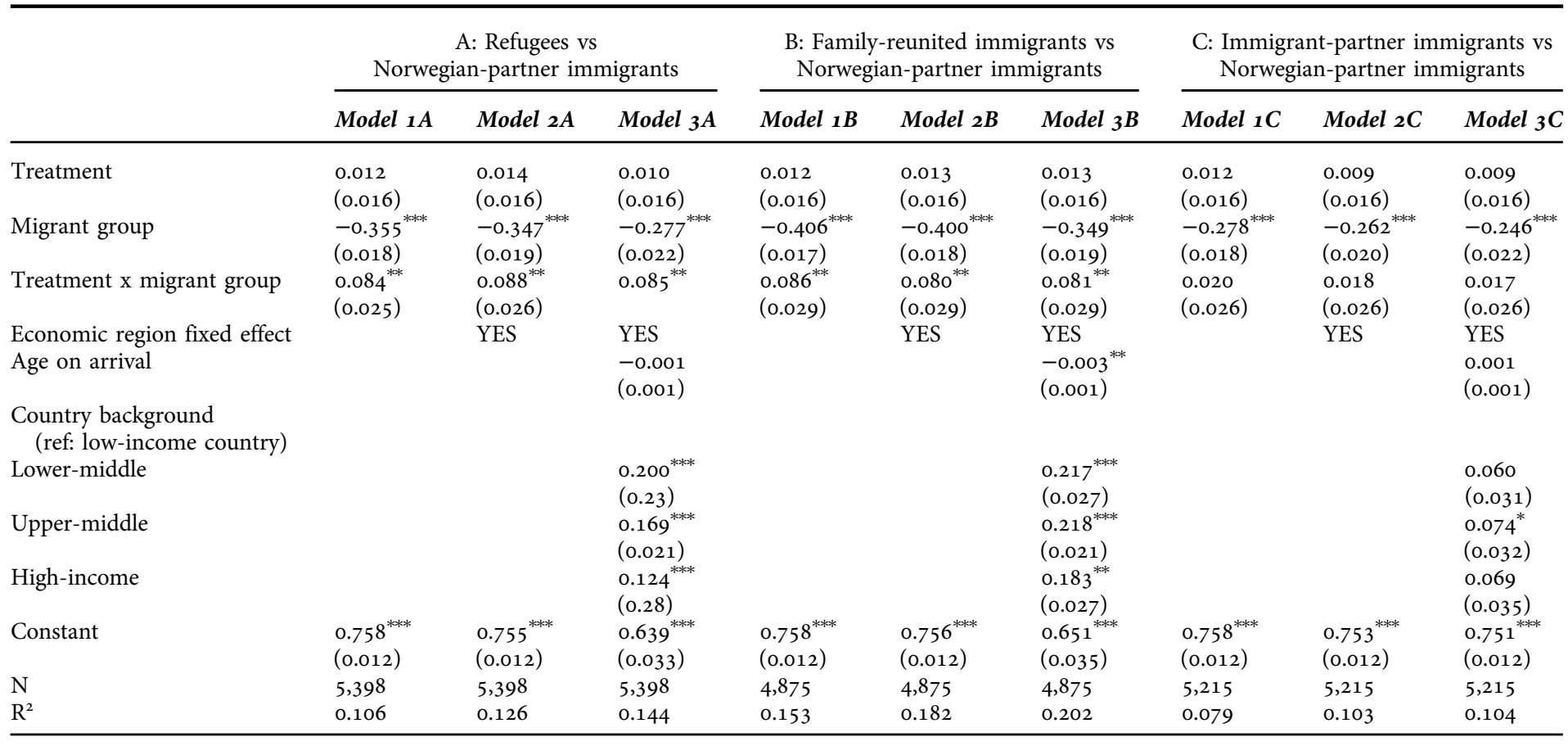


effects for economic region in Model 2 and controls for age on arrival and WBCc in Model 3 reduces the estimates, which are due to different control groups: however, it does not alter the treatment effect of the NIP.

As a robustness check, we included a third pair of immigrants (C). The argument was that the interaction term in this analysis could serve as a measure of whether any conditions other than the NIP could affect employment and earnings, such as seasonal variation in the labour market or biases in the immigrant population. This test is satisfied as neither of the estimates of the interaction terms is significant and this further strengthens our conviction that the positive and significant interaction terms among treated refugees and familyreunited immigrants measure a causal effect of the NIP on employment.

The analyses evaluating the effect of the NIP on earnings can be found in Appendix A1. In line with the analyses on the employment effect of the NIP, Norwegian-partner immigrants have better earnings prospects compared to refugees and family-reunited immigrants. However, it is interesting to note that none of the interaction terms is significant in any of these analyses, and thus do not support a positive effect of the NIP on refugees and family-reunited immigrants' earnings 4-6 years after immigration.

\section{The long-term effect of the NIP}

The study also hypothesised that the facilitation of early vocational training upon arrival in addition to the increase in host-country human capital could lead to jobs with better earnings prospects. If so, we would expect the NIP to have long-lasting positive effects on employment and earnings prospects among treated refugees and family-reunited immigrants $\left(\mathrm{H}_{2}\right)$.

Table 3 presents the long-term effect of the NIP on employment. Column A refers to the results for refugees versus Norwegian-partner immigrants. The results show that $78 \%$ of the Norwegian-partner immigrants were employed 7-9 years after immigration, and no differences were found between those who immigrated before versus after the reform. The probability of employment is 33-percentage points lower among non-treated refugees compared to Norwegian-partner immigrants. The interaction term shows that treated refugees have a 9-percentage point higher probability of employment 7-9 years after immigration compared to non-treated refugees.

The analysis of the second pair of immigrants (B) shows that familyreunited immigrants have a 40-percentage point lower probability of employment 7-9 years after immigration compared to Norwegian-partner immigrants. Moreover, treated family-reunited immigrants have an 8-percentage point higher probability of employment 7-9 years after immigration compared to non-treated family-reunited immigrants.

The inclusion of fixed effects for economic region (Model 2) and controls for age on arrival and WBcc (Model 3 ) do not alter the treatment effect of the 
TABLE 3. Linear probability model of immigrants' employment 7-9 years after immigration to Norway

\begin{tabular}{|c|c|c|c|c|c|c|c|c|c|}
\hline & \multicolumn{3}{|c|}{$\begin{array}{c}\text { A: Refugees vs } \\
\text { Norwegian-partner immigrants }\end{array}$} & \multicolumn{3}{|c|}{$\begin{array}{l}\text { B: Family-reunited immigrants vs } \\
\text { Norwegian-partner immigrants }\end{array}$} & \multicolumn{3}{|c|}{$\begin{array}{l}\text { C: Immigrant-partner immigrants vs } \\
\text { Norwegian-partner immigrants }\end{array}$} \\
\hline & Model $1 A$ & Model $2 A$ & Model $3 A$ & Model 1 B & Model $2 B$ & Model 3 B & Model $1 \mathrm{C}$ & Model $2 \mathrm{C}$ & Model ${ }_{3} C$ \\
\hline IP-eligible & $\begin{array}{l}0.003 \\
(0.016)\end{array}$ & $\begin{array}{l}0.005 \\
(0.016)\end{array}$ & $\begin{array}{c}0.004 \\
(0.016)\end{array}$ & $\begin{array}{l}0.003 \\
(0.016)\end{array}$ & $\begin{array}{c}0.004 \\
(0.016)\end{array}$ & $\begin{array}{l}0.006 \\
(0.016)\end{array}$ & $\begin{array}{l}0.003 \\
(0.016)\end{array}$ & $\begin{array}{l}0.005 \\
(0.016)\end{array}$ & $\begin{array}{l}0.004 \\
(0.016)\end{array}$ \\
\hline Migrant group & $\begin{array}{l}-0.327^{* * *} \\
(0.018)\end{array}$ & $\begin{array}{l}-0.327^{* * *} \\
(0.019)\end{array}$ & $\begin{array}{c}-0.232^{* * *} \\
(0.022)\end{array}$ & $\begin{array}{l}-0.393^{* * *} \\
(0.017)\end{array}$ & $\begin{array}{c}-0.381^{* * *} \\
(0.018)\end{array}$ & $\begin{array}{l}-0.323^{* * *} \\
(0.019)\end{array}$ & $\begin{array}{l}-0.263^{* * * *} \\
(0.018)\end{array}$ & $\begin{array}{l}-0.234^{* * *} \\
(0.020)\end{array}$ & $\begin{array}{l}-0.217^{* * *} \\
(0.022)\end{array}$ \\
\hline IP-eligible $\mathrm{x}$ migrant group & $\begin{array}{l}0.089^{* * *} \\
(0.025)\end{array}$ & $\begin{array}{l}0.087^{* *} \\
(0.025)\end{array}$ & $\begin{array}{l}0.076^{* *} \\
(0.025)\end{array}$ & $\begin{array}{l}0.081^{* *} \\
(0.029)\end{array}$ & $\begin{array}{l}0.080^{* *} \\
(0.029)\end{array}$ & $\begin{array}{l}0.072^{*} \\
(0.028)\end{array}$ & $\begin{array}{c}0.019 \\
(0.026)\end{array}$ & $\begin{array}{c}0.015 \\
(0.026)\end{array}$ & $\begin{array}{c}0.010 \\
(0.026)\end{array}$ \\
\hline $\begin{array}{l}\text { Economic region fixed effect } \\
\text { Age on arrival }\end{array}$ & & YES & $\begin{array}{c}\text { YES } \\
-0.005^{* * *} \\
(0.001)\end{array}$ & & YES & $\begin{array}{c}\text { YES } \\
-0.006^{* * *} \\
(0.001)\end{array}$ & & YES & $\begin{array}{c}\text { YES } \\
-0.002^{*} \\
(0.001)\end{array}$ \\
\hline $\begin{array}{l}\text { Country background } \\
\text { (ref: low-income country) }\end{array}$ & & & & & & & & & \\
\hline Lower-middle & & & $\begin{array}{l}0.271^{* * *} \\
(0.022)\end{array}$ & & & $\begin{array}{l}0.219^{* * *} \\
(0.028)\end{array}$ & & & $\begin{array}{l}0.070^{*} \\
(0.032)\end{array}$ \\
\hline Upper-middle & & & $\begin{array}{l}0.198^{* * * *} \\
(0.022)\end{array}$ & & & $\begin{array}{l}0.204^{* * *} \\
(0.022)\end{array}$ & & & $\begin{array}{l}0.087^{* *} \\
(0.033)\end{array}$ \\
\hline High-income & & & $\begin{array}{l}0.215^{* * *} \\
(0.027)\end{array}$ & & & $\begin{array}{l}0.222^{* * *} \\
(0.027)\end{array}$ & & & $\begin{array}{l}0.130^{* * *} \\
(0.035)\end{array}$ \\
\hline Constant & $\begin{array}{l}0.779^{* * *} \\
(0.011)\end{array}$ & $\begin{array}{l}0.779^{* * *} \\
(0.011)\end{array}$ & $\begin{array}{l}0.716^{* * *} \\
(0.032)\end{array}$ & $\begin{array}{l}0.779^{* * *} \\
(0.011)\end{array}$ & $\begin{array}{l}0.774^{* * *} \\
(0.011)\end{array}$ & $\begin{array}{l}0.754^{* * *} \\
(0.036)\end{array}$ & $\begin{array}{l}0.779^{* * *} \\
(0.011)\end{array}$ & $\begin{array}{l}0.768^{* * *} \\
(0.012)\end{array}$ & $\begin{array}{c}0.736^{* * *} \\
(0.043)\end{array}$ \\
\hline $\mathrm{N}$ & 5,398 & 5,398 & 5,398 & 4,875 & 4,875 & 4,875 & 5,215 & 5,215 & 5,215 \\
\hline $\mathrm{R}^{2}$ & 0.090 & 0.114 & 0.146 & 0.144 & 0.166 & 0.191 & 0.072 & 0.095 & 0.098 \\
\hline
\end{tabular}


NIP on refugees and family-reunited immigrants' employment 7-9 years after immigration. It is reassuring to see that the NIP has no effect on immigrantpartner immigrants' employment 7-9 years after immigration, implying a positive long-term effect of the NIP on refugees and family-reunited immigrants' employment.

Analyses evaluating the long-term earning effects of the NIP can be found in Appendix A2. The results indicate no significant effect of the NIP on longterm earnings prospects among treated refugees and family-reunited immigrants. However, it is worth noting that the earning gap between refugees and Norwegian-partner immigrants was significantly lower 4-6 years after immigration. This earning gap is no longer significant 7-9 years after immigration indicating an increase in their earnings over time relative to Norwegianpartner immigrants - a similar trend is not found among family-reunited immigrants.

\section{Concluding discussion}

The effect of the NIP is identified by comparing the employment and earning gaps between refugees and family-reunited immigrants and Norwegian-partner immigrants, not eligible for the NIP, before and after the introduction of the NIP. An analogue comparison between immigrant-partner immigrants, not covered by the reform, and the Norwegian-partner immigrants is included as a robustness test. The study demonstrates that treated refugees and familyreunited immigrants have a significantly higher probability of both short-term and long-term employment compared to non-treated refugees and familyreunited immigrants. In contrast, the NIP has no such effect on refugees' and family-reunited immigrants' earnings prospects.

Our results extend previous research findings by documenting an employment effect of the NIP among refugees and family-reunited immigrants: thus, partly deviating from a study presented in a Norwegian report (Røed et al., 2019), which suggests that the introduction of the NIP had no effect on employment. To the best of our knowledge, this is because our study has a narrower focus on the time span close to the reform date, includes AAC immigrants and uses a more nuanced division of family reunification, which enables us to use a stable control group that was not covered by the NIP. One argument for not using a shorter time window is that NIP-ineligible immigrants who immigrated close to the reform date may have benefitted from the NIP. Using a larger time window and removing all the people who immigrated during the year of implementation may reduce this problem (Røed et al., 2019). However, such a strategy may cause selection problems due to differences in immigration flows driven by areas in conflict or war, as well as unobservable characteristics among NIP-ineligible and NIP-eligible immigrants. We argue 
that the weakness of using a large time window presents greater selection problems than using a shorter time window that may underestimate the effect of the NIP. Additionally, our findings are in line with studies focusing on the correlation between language training and employment (Cheung and Phillimore, 2017; Clausen et al., 2009; Delander et al., 2005; Djuve et al., 2017; Sarvimäki and Hämäläinen, 2016), and vocational training or on-the-job training and employment (Butschek and Walter, 2014; Clausen et al., 2009; Heinesen et al. (2013).

In line with previous research (Djuve et al., 2017; Røed et al., 2019), our results do not support the assumption that the NIP would improve immigrants' skills to secure better jobs with good earnings prospects. Although the introduction of the NIP facilitated acquisition of host-country human capital, it had several shortcomings. First, the language training was not adapted to individual needs and was not sufficient to adequately improve their skills given the poor language skills of the majority upon arrival (Djuve et al, 2017). Secondly, although one of the stated goals of the NIP was, and remains, achievement of secondary education, few participants have benefitted due to poor language skills and lack of formal education upon arrival, resulting in many using the programme period to achieve primary education (Djuve and Kavli, 2019). The combination of few opportunities to increase formal skills within the programme period and the Norwegian labour market structure, characterised by high wages at the bottom end of the earnings distribution and very few jobs that do not require formal education, may be an obstacle for refugees' and familyreunited immigrants' earnings prospects.

However, why does the NIP affect treated refugees' and family-reunited immigrants' employment but not their earnings prospects? Given the limitations of the NIP and the poor opportunities to increase formal skills, as stated in previous research, this should affect both employment and earnings prospects. Our argument is that the combination of the relatively small effect of the NIP on employment and no effect on earnings implies a displacement effect rather than an increased host-country human capital effect. Treated refugees and familyreunited immigrants might be employed at the expense of refugees and familyreunited immigrants who immigrated 18 months before implementation of the programme, and thus did not benefit from the NIP. This is because non-treated and treated refugees and family-reunited immigrants applied for jobs, to a great extent, in the same labour market, where immigrants covered by the reform may have been positively selected for on-the-job training and support from the Norwegian Labour and Welfare Administration, which in turn affects employment opportunities. Contradictions in the Norwegian integration policy, focusing on both improving host-country human capital and the desire for early labour market attachment, may make adequate labour market integration difficult.

Previous research has documented an association between early labour market attachment and poor job quality and suggested that active labour market 
programmes need to focus more on job quality and not only on the effectiveness of early labour market attachment (Dengler, 2019). This may also be relevant to this study; although treated immigrants may be more employable, we do not know the quality of the jobs they get. Moreover, acquisition of host-country language might have a modest effect and should be understood in a broader context that shape immigrants' labour market opportunities (Nimer and Rottmann, 2020). As such, ethnic discrimination is documented in the Norwegian labour market (e.g. Larsen and Di Stasio, 2019), which means that even if immigrants possess human capital qualities equivalent to those of natives, immigrants' skills may be evaluated and rewarded differently by employers. Hence, the increase in host-country human capital through the NIP could be suppressed by conditions such as discrimination.

There are many advantages of using register data: however, it also has limitations. The register data lack information on the quality of the NIP and whether it was adapted to individual needs, which means we are unable to examine whether the different programme measures may have affected individuals differently. In addition, register data do not provide information about the quality of jobs, which is important for individual income development and career opportunities. Such information would benefit the present study's findings, and future research could benefit from more detailed measures of the acquisition of host-country language and work-related skills and job quality. This would elucidate whether differences between employment and mean earnings are due to a displacement effect or to an increase in host-country human capital.

Notwithstanding these limitations, our study demonstrates that introduction programmes aimed at newly arrived immigrants have a positive effect on employment. Although the Norwegian welfare state and the labour market differ in a number of areas, other countries will probably gain knowledge from this study, particularly the importance of including control groups not affected by the such reforms, and measures of both short- and long-term employment and earnings when evaluating integration programmes.

\section{Competing interests}

The authors declare none.

\section{Acknowledgements}

This article has benefited from valuable comments on the manuscript from Jon Ivar Elstad, Are Vegard Haug and Kristian Heggebø. We also thank two anonymous reviewers for their very valuable comments. All errors are the authors' own. This work was supported by the Research Council of Norway [grant number 237028 and 270838]. 


\section{Notes}

1 The average BA in the period 4-6 years after immigration was EUR 6,998 per year

2 The average BA in the period 7-9 years after immigration was EUR 7,899 per year

\section{References}

Åslund, O. and Johansson, P. (2011), 'Virtues of SIN: Can intensified public efforts help disadvantaged immigrants?', Evaluation Review 35(4): 399-427.

Angrist, J. D. and Pischke, J. S. (2009), Mostly Harmless Econometrics: An Empiricist's Companion, Economics Books: Princeton University Press.

Arendt, J. N., Nielsen, C. P. and Jakobsen, V. (2016), 'The Importance of Origin and Destination Country Skills for Labour Market Attachment of Immigrants from Pakistan, Iran and Turkey', Nordic Journal of Migration Research, 6:2, 72-80.

Becker, G. S. (1985), 'Human capital, effort, and the sexual division of labor', Journal of Labor Economics, 3, 33-58.

Bloch, A. (2007), 'Refugees in the UK labour market: the conflict between economic integration and policy-led labour market restriction', Journal of Social Policy, 37:1, 21-36.

Bratsberg, B. and Ragan, J.F. (2002), 'The Impact of Host Country Schooling on Earnings. A Study of Male Immigrants in the United States', The Journal of Human Resources 37:1, 64-105.

Bratsberg, B., Raaum, O. and Røed, K. (2017), 'Immigrant labor market integration across admission classes', Nordic Economic Policy Review, 2017, 520.

Butschek, S. and Walter, T. (2014), 'What active labour market programmes work for immigrants in Europe? A meta-analysis of the evaluation literature', IZA Journal of Migration 3:48.

Cheung, S. Y. and Phillimore, J. (2017), 'Gender and Refugee Integration: a Quantitative Analysis of Integration and Social Policy Outcomes', Journal of Social Policy, 46:2, 211-230.

Chiswick, B. R. and Miller, P. W. (2007), 'The economic cost to native-born Americans of limited English language proficiency', in B. R. Chiswick, and P. W. Miller (eds.) The economics of language: international analyses. London: Routledge, 413-430.

Chiswick, B. R. and Miller, P. W. (2010), Occupational language requirements and the value of English in the US labor market. Journal of Population Economics 23, 353-372.

Clausen, J., Heinesen, E., Hummelgaard, H., Husted, L. and Rosholm, M. (2009), 'The effect of integration policies on the time until regular employment of newly arrived immigrants: Evidence from Denmark', Labour Economics, 16(4), 409-417.

Delander, L., Hammarstedt, M., Månsson, J. and Nyberg, E. (2005), 'Integration of immigrants: The role of language proficiency and experience', Evaluation Review 29(1): 24-41.

Dengler, K. (2019), 'Effectiveness of Active Labour Market Programmes on the Job Quality of Welfare Recipients in Germany', Journal of social policy, 48:4, 807-838.

Djuve, A.B., Kavli, H.C., Sterri, E.B. and Bråten, B. (2017), Introduksjonsprogram og norskopplering. Hva virker - for hvem? Fafo-rapport 2017:3. Oslo: Fafo.

Djuve, A.B. and Kavli, H.C. (2019), 'Refugee integration policy the Norwegian way - why good ideas fail and bad ideas prevail', Transfer: European Review of Labour and Research, 25:1, 25-42

Dumper, H. (2002), 'Is it Safe Here?: Refugees, social capital, and labour market integration in the UK', Refugee Action.

Friedberg, R. M. (2000), 'You Can't Take It with You? Immigrant Assimilation and the Portability of Human Capital' Journal of Labor Economics 18:2, 221-51.

Hardoy, I. and Zhang, T. (2010), 'Innvandrere i arbeid: Hjelper arbeidsmarkedstiltak?' Søkelys på arbeidslivet 27(4): 343-364.

Heinesen, E., Husted, L. and Rosholm, M. (2013), 'The effects of active labour market policies for immigrants receiving social assistance in Denmark', IZA Journal of Migration, 2:15. 
Hernes, V., Arendt, J.N., Joona, P.A. and Tronstad, K.R. (2019), Nordic integration and settlement policies for refugees A comparative analysis of labour market integration outcomes, TemaNord 2019:529.

Joona, P.A. and Nekby, L. (2012), 'Intensive coaching of new immigrants: An evaluation based on random program assignment', The Scandinavian Journal of Economics 114(2): 575-600.

Larsen, E.N. and Di Stasio, V. (2019), 'Pakistani in the UK and Norway: different contexts, similar disadvantage. Results from a comparative field experiment on hiring discrimination', Journal of ethnic and migration studies, 1-21.

Nimer, M. and Rottmann, S. B. (2020), 'Migration Regime and "Language Part of Work": Experiences of Syrian Refugees as Surplus Population in the Turkish Labor Market', Critical Sociology, 1-14.

Pyrhönen, N., Leinonen, J. and Martikainen, T. (2017), 'Nordic migration and integration research: Overview and future prospects', NordForsk Policy Paper, 3, 3.

Røed, M., Schøne, P. and Umblijs, J. (2019), Flyktningers deltagelse i arbeid og utdanning, før og etter introduksjonsordningen, Institutt for samfunnsforskning: Rapport 2019:8

Sarvimäki, M. and Hämäläinen, K. (2016), 'Integrating immigrants: The impact of restructuring active labor market programs', Journal of Labor Economics 34(2): 479-508.

Schultz-Nielsen, M. L. (2017), 'Labour market integration of refugees in Denmark', Nordic Economic Policy Review, 2017, 520.

Shields, M. and Price, S. (2002), 'The English language fluency and occupational success of ethnic minority immigrant men living in English metropolitan areas', Journal of Population Economics, 15, 137-160.

White Paper No. 23 (2003-2004), Report No. 23 to the Storting. 
Appendix A1

TABLE A1. OLS model of immigrants' mean earnings 4-6 years after immigration to Norway

\begin{tabular}{|c|c|c|c|c|c|c|c|c|c|}
\hline & \multicolumn{3}{|c|}{$\begin{array}{l}\text { A: Refugees vs } \\
\text { Norwegian-partner } \\
\text { immigrants }\end{array}$} & \multicolumn{3}{|c|}{$\begin{array}{l}\text { B: Family-reunited } \\
\text { immigrants vs Norwegian- } \\
\text { partner immigrants }\end{array}$} & \multicolumn{3}{|c|}{$\begin{array}{l}\text { C: Immigrant-partner } \\
\text { immigrants vs } \\
\text { Norwegian-partner } \\
\text { immigrants }\end{array}$} \\
\hline & $\begin{array}{c}\text { Model } \\
1 A\end{array}$ & $\begin{array}{c}\text { Model } \\
2 A\end{array}$ & $\begin{array}{c}\text { Model } \\
3 A\end{array}$ & $\begin{array}{c}\text { Model } \\
1 B\end{array}$ & $\begin{array}{c}\text { Model } \\
2 B\end{array}$ & $\begin{array}{c}\text { Model } \\
3 B\end{array}$ & $\begin{array}{c}\text { Model } \\
{ }_{1} C\end{array}$ & $\begin{array}{l}\text { Model } \\
{ }_{2} \mathrm{C}\end{array}$ & $\begin{array}{c}\text { Model } \\
{ }_{3} \mathrm{C}\end{array}$ \\
\hline IP-eligible & $\begin{array}{c}0.013 \\
(0.0565)\end{array}$ & $\begin{array}{c}0.030 \\
(0.057)\end{array}$ & $\begin{array}{c}0.030 \\
(0.057)\end{array}$ & $\begin{array}{c}0.013 \\
(0.056)\end{array}$ & $\begin{array}{l}0.030 \\
(0.057)\end{array}$ & $\begin{array}{c}0.028 \\
(0.057)\end{array}$ & $\begin{array}{c}0.013 \\
(0.056)\end{array}$ & $\begin{array}{c}0.016 \\
(0.057)\end{array}$ & $\begin{array}{c}0.015 \\
(0.057)\end{array}$ \\
\hline Migrant group & $\begin{array}{c}-0.223^{* * *} \\
(0.081)\end{array}$ & $\begin{array}{c}-0.179^{*} \\
(0.083)\end{array}$ & $\begin{array}{l}-0.057 \\
(0.098)\end{array}$ & $\begin{array}{c}-0.223^{* * *} \\
(0.082)\end{array}$ & $\begin{array}{c}-0.251^{* * *} \\
(0.083)\end{array}$ & $\begin{array}{c}-0.172^{*} \\
(0.086)\end{array}$ & $\begin{array}{l}-0.061 \\
(0.078)\end{array}$ & $\begin{array}{l}-0.139 \\
(0.084)\end{array}$ & $\begin{array}{l}-0.052 \\
(0.090)\end{array}$ \\
\hline $\begin{array}{l}\text { IP-eligible } X \\
\text { migrant group }\end{array}$ & $\begin{array}{c}0.003 \\
(0.105)\end{array}$ & $\begin{array}{c}0.006 \\
(0.108)\end{array}$ & $\begin{array}{c}0.012 \\
(0.107)\end{array}$ & $\begin{array}{c}0.132 \\
(0.132)\end{array}$ & $\begin{array}{c}0.070 \\
(0.133)\end{array}$ & $\begin{array}{c}0.086 \\
(0.132)\end{array}$ & $\begin{array}{l}-0.048 \\
(0.105)\end{array}$ & $\begin{array}{l}-0.038 \\
(0.107)\end{array}$ & $\begin{array}{l}-0.045 \\
(0.106)\end{array}$ \\
\hline $\begin{array}{l}\text { Economic region } \\
\text { fixed effect }\end{array}$ & & YES & YES & & YES & YES & & YES & YES \\
\hline Age on arrival & & & $\begin{array}{l}0.017^{* * * * *} \\
(0.003)\end{array}$ & & & $\begin{array}{l}0.017^{* * * * *} \\
(0.004)\end{array}$ & & & $\begin{array}{l}0.019^{* * * * k} \\
(0.004)\end{array}$ \\
\hline $\begin{array}{l}\text { Country } \\
\text { background } \\
\text { (ref: low-income } \\
\text { country) }\end{array}$ & & & & & & & & & \\
\hline Lower-middle & & & $\begin{array}{l}0.113 \\
(0.087)\end{array}$ & & & $\begin{array}{l}0.416^{\text {*** }} \\
(0.126)\end{array}$ & & & $\begin{array}{l}0.312^{*} \\
(0.120)\end{array}$ \\
\hline Upper-middle & & & $\begin{array}{l}0.217^{*} \\
(0.091)\end{array}$ & & & $\begin{array}{l}0.366^{* *} \\
(0.113)\end{array}$ & & & $\begin{array}{l}0.294^{*} \\
(0.119)\end{array}$ \\
\hline High-income & & & $\begin{array}{l}0.231^{* *} \\
(0.106)\end{array}$ & & & $\begin{array}{l}0.390^{* * *} \\
(0.123)\end{array}$ & & & $\begin{array}{c}0.313^{*} \\
80.127)\end{array}$ \\
\hline Constant & $\begin{array}{l}3.443^{* * * * *} \\
(0.042)\end{array}$ & $\begin{array}{c}3.402^{* * * * *} \\
(0.042)\end{array}$ & $\begin{array}{l}2.693^{* * * * *} \\
(0.136)\end{array}$ & $\begin{array}{l}3.427^{* * * *} \\
(0.042)\end{array}$ & $\begin{array}{l}3.431^{* * * *} \\
(0.042)\end{array}$ & $\begin{array}{l}2.549^{* * * * *} \\
(0.153)\end{array}$ & $\begin{array}{l}3.427^{* * * * *} \\
(0.042)\end{array}$ & $\begin{array}{l}3.449^{\text {**** }} \\
(0.042)\end{array}$ & $\begin{array}{l}2.575^{\text {*wek }} \\
(0.161)\end{array}$ \\
\hline $\mathrm{N}$ & 2,977 & 2,977 & 2,977 & 2,623 & 2,623 & 2,623 & 2,983 & 2,983 & 2,983 \\
\hline $\mathrm{R}^{2}$ & 0.065 & 0.052 & 0.063 & 0.024 & 0.052 & 0.064 & 0.001 & 0.036 & 0.048 \\
\hline
\end{tabular}




\section{Appendix A2}

TABLE A2. OLS model of immigrants' mean earnings 7-9 years after immigration to Norway

\begin{tabular}{|c|c|c|c|c|c|c|c|c|c|}
\hline & \multicolumn{3}{|c|}{$\begin{array}{l}\text { A: Refugees vs } \\
\text { Norwegian-partner } \\
\text { immigrants }\end{array}$} & \multicolumn{3}{|c|}{$\begin{array}{l}\text { B: Family-reunited } \\
\text { immigrants vs Norwegian- } \\
\text { partner immigrants }\end{array}$} & \multicolumn{3}{|c|}{$\begin{array}{l}\text { C: Immigrant-partner } \\
\text { immigrants vs } \\
\text { Norwegian-partner } \\
\text { immigrants }\end{array}$} \\
\hline & $\begin{array}{c}\text { Model } \\
\text { A1 }\end{array}$ & $\begin{array}{c}\text { Model } \\
\text { A2 }\end{array}$ & $\begin{array}{c}\text { Model } \\
A_{3}\end{array}$ & $\underset{B 1}{\text { Model }}$ & $\begin{array}{c}\text { Model } \\
\text { B2 }\end{array}$ & $\begin{array}{c}\text { Model } \\
\mathrm{B}_{3}\end{array}$ & $\begin{array}{c}\text { Model } \\
\text { C1 }\end{array}$ & $\begin{array}{c}\text { Model } \\
\text { C1 }\end{array}$ & $\begin{array}{c}\text { Model } \\
\text { C1 }\end{array}$ \\
\hline Treatment & $\begin{array}{l}-0.007 \\
(0.059)\end{array}$ & $\begin{array}{l}-0.014 \\
(0.060)\end{array}$ & $\begin{array}{l}-0.018 \\
(0.060)\end{array}$ & $\begin{array}{l}-0.007 \\
(0.059)\end{array}$ & $\begin{array}{l}-0.014 \\
(0.060)\end{array}$ & $\begin{array}{l}-0.018 \\
(0.060)\end{array}$ & $\begin{array}{l}-0.007 \\
(0.059)\end{array}$ & $\begin{array}{l}-0.020 \\
(0.060)\end{array}$ & $\begin{array}{l}-0.018 \\
(0.060)\end{array}$ \\
\hline Migrant group & $\begin{array}{l}-0.083 \\
(0.082)\end{array}$ & $\begin{array}{l}-0.063 \\
(0.083)\end{array}$ & $\begin{array}{l}-0.077 \\
(0.102)\end{array}$ & $\begin{array}{c}-0.179^{*} \\
(0.083)\end{array}$ & $\begin{array}{c}-0.207^{*} \\
(0.083)\end{array}$ & $\begin{array}{l}-0.148 \\
(0.090)\end{array}$ & $\begin{array}{l}-0.089 \\
(0.080)\end{array}$ & $\begin{array}{l}-0.164 \\
(0.084)\end{array}$ & $\begin{array}{l}-0.054 \\
(0.093)\end{array}$ \\
\hline $\begin{array}{l}\text { Treatment X migrant } \\
\text { group }\end{array}$ & $\begin{array}{l}-0.023 \\
(0.105)\end{array}$ & $\begin{array}{l}-0.005 \\
(0.107)\end{array}$ & $\begin{array}{l}-0.014 \\
(0.106)\end{array}$ & $\begin{array}{l}-0.098 \\
(0.130)\end{array}$ & $\begin{array}{l}-0.131 \\
(0.130)\end{array}$ & $\begin{array}{l}-0.113 \\
(0.129)\end{array}$ & $\begin{array}{l}0.030 \\
(0.111)\end{array}$ & $\begin{array}{c}0.045 \\
(0.113)\end{array}$ & $\begin{array}{c}0.036 \\
(0.112)\end{array}$ \\
\hline $\begin{array}{l}\text { Economic region fixed } \\
\text { effect }\end{array}$ & & YES & YES & & YES & YES & & YES & YES \\
\hline Age on arrival & & & $\begin{array}{l}0.018^{\text {*ask }} \\
(0.003)\end{array}$ & & & $\begin{array}{l}0.018^{\text {*a冰* }} \\
(0.004)\end{array}$ & & & $\begin{array}{l}0.016^{* \text { ***4 }} \\
(0.004)\end{array}$ \\
\hline $\begin{array}{l}\text { Country background } \\
\text { (ref: low-income } \\
\text { country) }\end{array}$ & & & & & & & & & \\
\hline Lower-middle & & & 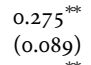 & & & $\begin{array}{l}0.395^{* *} \\
(0.136)\end{array}$ & & & $\begin{array}{c}0.146 \\
(0.139)\end{array}$ \\
\hline Upper-middle & & & $\begin{array}{l}0.261^{* *} \\
(0.096)\end{array}$ & & & $\begin{array}{l}0.246^{*} \\
(0.117)\end{array}$ & & & $\begin{array}{l}0.205 \\
(0.143)\end{array}$ \\
\hline High-income & & & $\begin{array}{l}0.309^{\text {冰 }} \\
(0.112)\end{array}$ & & & $\begin{array}{l}0.303^{*} \\
(0.128)\end{array}$ & & & $\begin{array}{c}0.261 \\
(0.149)\end{array}$ \\
\hline Constant & $\begin{array}{l}3.704^{* * * * *} \\
(0.043)\end{array}$ & $\begin{array}{l}3.697^{* * * *} \\
(0.043)\end{array}$ & $\begin{array}{l}2.881^{\text {*okk }} \\
(0.138)\end{array}$ & $\begin{array}{l}3.704^{* * \ldots k} \\
(0.043)\end{array}$ & $\begin{array}{l}3.717^{* * k * k} \\
(0.043)\end{array}$ & $\begin{array}{l}2.903^{* \cdot * * *} \\
(0.165)\end{array}$ & $\begin{array}{l}3.704^{* * * * *} \\
(0.043)\end{array}$ & $\begin{array}{l}3.734^{* * * * k} \\
(0.044)\end{array}$ & $\begin{array}{l}3.042^{\text {**** }} \\
(0.176)\end{array}$ \\
\hline $\mathrm{N}$ & 3,220 & 3,220 & 3,220 & 2,792 & 2,792 & 2,792 & 3,166 & 3,166 & 3,166 \\
\hline $\mathrm{R}^{2}$ & 0.001 & 0.043 & 0.055 & 0.005 & 0.049 & 0.059 & 0.001 & 0.033 & 0.040 \\
\hline
\end{tabular}

